\title{
CONSTITUTIONAL EQUITY AND THE INNOVATIVE TRADITION
}

\author{
WILLIAM T. QUILLEN ${ }^{*}$
}

\section{INTRODUCTION}

Lazard Freres \& Company ("Lazard") and Dillon Read \& Company, Inc. ("Dillon"), the investment bank advisers to the special committee of the board of directors of RJR Nabisco, Inc. ("RJR"), ${ }^{1}$ moved to intervene in the recent Nabisco shareholder litigation in the Delaware Court of Chancery. ${ }^{2}$ The motion presented the court with the stuff of lawyers-personal jurisdiction, subject matter jurisdiction, mandatory counterclaims, mandatory and permissive intervention, declaratory judgments, collateral estoppel-in short, a feast for those of our craft who are determined that the elimination of common law pleading and antiquated bills in equity shall not spoil all the fun. ${ }^{3}$ The motion to intervene was presented to Chancellor William T. Allen, Chief Judge of the Delaware Court of Chancery.

What is striking about the portion of the opinion dealing with subject matter jurisdiction is not its example of a now-rare breed of legal issues (that is, is the declaratory judgment counterclaim, being a strictly legal matter designed to negate liability for negligence, cognizable in a separate court of equity?), nor even the overall issues of the modern uniqueness of the Delaware bifurcated

\section{Copyright $\odot 1993$ by William T. Quillen}

* Delaware Secretary of State; Distinguished Visiting Professor of Law, Widener University School of Law, Wilmington, Delaware; former Chancellor, Delaware Court of Chancery; retired Justice, Delaware Supreme Court.

This article is largely taken from a longer work. See William T. Quillen, A Historical Sketch of the Equity Jurisdiction in Delaware (1982) (unpublished LL.M. thesis, University of Virginia) [hereinafter Quillen, Historical Sketch]. Another article based on the same thesis was previously published in Delaware Lawyer. William T. Quillen, Equity Jurisdiction in Delaware Before 1792, 2 DEL. LAW. 18 (1984) [hereinafter, Quillen, Equity Jurisdiction].

The author expresses appreciation to his student research assistant at the Widener University School of Law, Nicole F. Autieri, and to Linda Hahs of The Delaware Journal of Corporate Law for their help in the preparation of this article.

1. See In re RJR Nabisco, Inc. Shareholders Litig., Del. Ch., 576 A.2d 654 (1990).

2. Delaware no longer has an official state reporter system on either the law or equity side. The proper form of case citation is governed by Supreme Court Rules 14(g) and 93(c), the former stating in part that "[a]ll further references to the previous State Reporter System shall be omitted." Delaware case citations herein will be in accordance with the Delaware practice.

3. The investment banks sought to intervene as defendants in a shareholder class action brought against RJR, its directors, Kohlberg Kravis Roberts \& Co. ("KKR"), and affiliates after an auction sale of RJR. After losing a preliminary injunction application that sought to enjoin KKR's tender offer for RJR's stock, the plaintiffs sued Lazard and Dillon in New York. The banks filed for a stay of the New York action, offering to submit to Delaware jurisdiction in the earlier action arising out of the same transaction. The intervention motion sought to assert a declaratory judgment counterclaim. 
structural context (that is, why not merge the courts, Delaware?). It is rather the perspective the chancellor gives to the example:

The question of subject matter jurisdiction involves ... the Delaware specialty of carrying forward and applying in fresh fields the ancient distinctions generated by the law-equity split. In working in this particular area, Delaware judges bear a particular responsibility to assist in the evolution of a workable body of rules that permits our divided system to achieve efficiency, while maintaining the special utility that this ancient division offers in the late 20th Century world. ${ }^{4}$

The chancellor went on to opine that, even if the proposed legal counterclaim, a new legal theory, were being "asserted by a permissive intervenor," subject matter jurisdiction should be sustained. ${ }^{5}$ He reached backwards to a traditional equitable maxim: "[I]t is the tradition of equity courts ordinarily to take up the whole case, not parts of it." But he embraced the factual emphasis of current procedure: "[M]odern approaches to jurisdiction focus not upon the various legal theories that can be embossed upon the facts, but upon the facts themselves in determining what constitutes a "cause of action' or "claim."” Finding that "the counterclaim appear[ed] to present a new legal theory of the already pleaded facts," the chancellor upheld ancillary jurisdiction to hear the proposed counterclaim: "To hold otherwise is not compelled by our statutes or decided cases and would contribute to a wooden and unproductive jurisprudence concerning the operation of our dual jurisdiction court system." 8

The purpose of this article is to show how a "dual jurisdiction court system" came to be constitutionally cemented in the Delaware legal landscape and to suggest the creative "particular responsibility" described by Chancellor Allen is useful legal art.

II

\section{CONSTITUTIONAL AND STATUTORY AUTHORITY FOR THE COURT OF} CHANCERY

In 1992, the court of chancery celebrated its 200th anniversary. Chancellor Allen is only the nineteenth person to hold the office. While the court is generally known for major corporate litigation, ${ }^{9}$ it is important to note that it is a traditional court of general equity jurisdiction. General equity jurisdiction was clearly proclaimed in Delaware's second Constitution: "The equity jurisdiction heretofore exercised by the Judges of the Court of Common Pleas, shall be

4. In re $R J R, 576 \mathrm{~A} .2 \mathrm{~d}$ at 658.

5. Id. at 659 .

6. Id. (citing 1 JOHN N. POMEROY, POMEROY's EQUITY JURISPRUDENCE $\S \S 181,231-43$ (Spencer W. Symons ed., Sth ed. 1941)).

7. Id. (citing RESTATEMENT (SECOND) OF JUDGMENT \& 24 (1982)).

8. $I d$.

9. See, e.g., Paramount Communications, Inc. v. Time, Inc., Del. Ch., No. 10,866 (July 14, 1989) (revised July 17, 1989), reprinted in 15 DEL. J. CORP. L. 700 (1990), affd, Del. Supr., 571 A.2d 1140 (1989) (Allen, C.). 
separated from the common law jurisdiction, and vested in a Chancellor, who shall hold Courts of Chancery in the several counties of this state . . .."10

Historic instincts naturally focus on the word "separated," a word connoting change, context, and complexity. Thus, while it is cause for celebration that the separate court of chancery has become a mature institution entering its third century, the equity tradition in Delaware springs from a merged system, not only during the early days of statehood (1776-1792), but also during its English colonial period dating from the first English conquest in $1664 .^{11}$ A secondary focus is more obscure, requiring one to join an allocation of jurisdiction with constitutional permanence, a focus on the seemingly innocuous word "vested."

One hundred and fifty-three years passed before the significance of the constitutional creation of the separate court of chancery in 1792 was definitively realized. During that period, the separate court embodied in the person of the chancellor had been preserved in Delaware's third Constitution in 1831 and its fourth Constitution in 1897. Delaware law had been largely shaped by the distinctive character of the chancellor. From Chancellor William Killen in 1793 to Chancellor William Watson Harrington in 1945, inclusive, only twelve men held the office. It was not until 1939 that a single statutory position of vice chancellor was created, and his decisions were still subject to approval by the chancellor in $1945 .^{12}$

Under the original design of the Constitution of 1897, there was no independent supreme court. Rather, the supreme court consisted of the chancellor and the law judges on the superior court, the constitutional law court of general jurisdiction. As the highest judicial officer, the chancellor presided. Ironically, however, since the Constitution excluded the chancellor from the supreme court upon an appeal from the court of chancery, the final appellate word on equitable matters was spoken exclusively by law judges. ${ }^{13}$

\section{A. Glanding v. Industrial Trust Co.}

In the context of the original design of the Constitution of 1897, an appeal was taken in 1944 from a court of chancery decree of distribution rendered by

10. DElaware ConST. of 1792 , art. VII, $\S 14$.

11. See Quillen, Historical Sketch, supra note *, at 20-126; Quillen, Equity Jurisdiction, supra note * (providing some of the early history). See also William T. Quillen \& Michael Hanrahan, A Short History of the Delaware Court of Chancery, 1792-1992, in COURT OF CHANCERY OF THE STATE OF DELAWARE, 1792-1992 (1992) (published in connection with the commemoration of the court's 200th anniversary). Since state legal history is generally an area of considerable neglect, the author has included in this article some glimpses of Delaware history including footnote capsules of basic biographic data of some prominent Delaware judges.

12. 42 Del. Laws ch. 148 (1939). It was not until 1949 that the position of vice chancellor became an independently recognized constitutional office. 47 Del. Laws ch. 177 (1949). A second vice chancellor was authorized in 1961. 53 Del. Laws ch. 5 (1961). The court now consists of five judges. 64 Del. Laws ch. 218 (1984); 67 Del. Laws ch. 1 (1989).

13. See DEL. ConST. of 1897 art. IV, $\$ \S 13-14$, in Revised Code of Delaware 1935, at xxix. The chancellor's position as the highest judicial officer had existed since the 1792 Constitution, which directed that he should preside over the then styled "The High Court of Errors and Appeal." DEL. CONST. of 1792, art. VII. 
the chancellor on the petition by the administrator with the will annexed. ${ }^{14}$ The law judges, constituting the supreme court on the appeal, themselves raised the question of the jurisdiction of the court of chancery. This led to the landmark Delaware case of Glanding v. Industrial Trust $\mathrm{Co}^{15}$

Since early colonial times, a court of special jurisdiction in estate and guardianship matters, known as an orphans' court, had existed in Delaware. ${ }^{16}$ The equitable nature of the court's limited jurisdiction caused some confusion over the years as to its role in the judicial system. The situation was further complicated by the fact that the orphans' court was staffed by the judges of the other courts in differing forms at various periods of its existence. ${ }^{17}$ Among other things, the statutes governing the orphans' court gave it the authority to enter decrees of distribution in estate matters. ${ }^{18}$

To the supreme court, this authority raised the question of the jurisdiction of the court of chancery. Section twenty-five of the colonial Gordon Statute, ${ }^{19}$ limiting the jurisdiction of the court of chancery, had continued as part of Delaware's statutory law ever since its enactment by the colonial assembly. In 1945, it appeared as part of the State's codified law, in the following language:

Provided, that the Chancellor shall not have power to determine any matter wherein sufficient remedy may be had by common law, or statute, before any other Court, or jurisdiction, of this State; but that where matters, determinable at common law, shall be brought before him in equity, he shall remit the parties to the common law; and when matters of fact, proper to be tried by a Jury, shall

14. Industrial Trust Co. v. Glanding, Del. Ch., 38 A.2d 752 (1944), aff d, Del. Supr., 45 A.2d 553 (1945).

15. Del. Supr., 45 A.2d 553 (1945).

16. The Glanding opinion erroneously says the orphans' court was created by the statute of 1721 . Id. at 557. While that statute may have been the first by the independent Lower Three County (later Delaware) Assembly to define the jurisdiction, an orphans' court existed from the early days of William Penn's rule. See William H. Loyd, The Early CourTs of PenNSYllvania ch. V, at 212-40 (1910); COURT RECORDS OF KeNT COUNTY, DElaware 1680-1705, KENT RECords, Historical INTRODUCTION xx (Leon DeValinger, Jr. ed., 1959).

17. The relationship of the orphans' court to the court of chancery and the law courts would take a separate paper to explore. The chancellor himself was for a long period of time, including 1897 to 1951 , a judge of the orphans' court, though not originally in 1792 and not at the demise of the orphans' court in 1970. See 56 Del. Laws ch. 147 (1967) (constitutional amendment enabling the General Assembly to abolish the Court); 57 Del. Laws ch. 402 (1970) (abolishing the court). The court of chancery, however, ultimately consumed the bulk of the jurisdiction of the orphans' court.

18. See 42 Del. Laws ch. 143 (1939) (now repealed 59 Del. Laws ch. 384 (1974)). The statute granting the orphans' court such authority was formerly and most recently codified at DEL. CODE ANN., tit. 12, \$§ 2331-2339 (1953). Now that authority lies within the court of chancery's jurisdiction. Id.

19. 1 Del. Laws ch. LIV, at 132 (circa 1727). The Gordon Statute, so named because it was enacted during Patrick Gordon's term as Governor (1726-1736), is the single most important enactment in the development of equity jurisdiction in Delaware. See Quillen, Equity Jurisdiction, supra note *, at 23-24, particularly n.14. The original language of the "sufficient remedy" limitation of $\S 25 \mathrm{read}$ as follows:

Provided also, That nothing herein contained shall give the said justices any power or authority to hear, decree or determine in equity, any matter, cause or thing, wherein sufficient remedy may be had in any other court or before any other magistrate or judicature in this government, either by the rules of the common law, or according to the tenor and directions of the law of this government, but when matters determinable at common law shall be brought before them in equity, they shall refer or remit the parties to the common law.... 
arise in any cause depending in Chancery, the Chancellor shall order such facts to trial by issues at the bar of the Superior Court. ${ }^{20}$

The question in Glanding simply was whether the statutory power in the orphans' court to enter a decree of distribution was a "sufficient remedy" to require the chancellor to "remit the parties to the common law ...."11 The five law judges divided three to two on the question with the majority upholding the jurisdiction of the chancellor sitting in the court of chancery.

The opinion of the court was delivered by Judge Terry. ${ }^{22}$ Preliminarily, the court focused on what jurisdiction had been vested in the court of chancery. The majority quickly concluded without apparent difficulty, and the dissent agreed, that the Constitutions of 1897 and 1831 did not create, but continued, the equity jurisdiction, and that the reference in the 1792 Constitution to the "equity jurisdiction heretofore exercised by the judges of the court of common pleas" had to be traced back through the Constitution of 1776 to the Gordon Statute. Under section twenty-one of the Gordon Statute, the court determined that "all of the jurisdiction theretofore exercised by the High Court of Chancery of Great Britain was ... conferred." ${ }^{23}$ Holding that the English Court had jurisdiction to enter a decree of distribution "from the close of the reign of Charles II," the first hurdle was crossed. ${ }^{24}$

The second hurdle, the old section twenty-five, divided the court. The majority announced the following conclusions: "(1) that the Legislature in enacting Section 25 did nothing more than declare the existence of an equitable principle, which in fact existed without its enactment; and (2) that no positive restriction or limitation of the exercise of equitable jurisdiction resulted therefrom." 25 The court reached this conclusion by favoring the line of case law holding that the "sufficiency remedy" limitation was merely "declaratory of a limitation established from ancient times irrespective of statutes,"26 rather than

20. REVISED CODE OF DELAwARE 1935, ch. 117, $\$ 4367$, at 922 (emphasis added). It should be noted that both limitations in the original Gordon Statute-the restriction as to sufficient remedy at law and the restriction as to the trial of facts-still appeared in modified form. Glanding was directed only to the first. 45 A.2d 553 .

21. See supra note 19.

22. Charles L. Terry, Jr., served the State as Secretary of State (1937-1938), Judge of the Superior Court (1938-1957), President Judge of the Superior Court (1957-1962), Justice of the Supreme Court (1962-1963), Chief Justice of the Supreme Court (1963-1964), and Governor (1965-1969). He died in 1970 at the age of 69. See Proceedings in Memory of the Late Honorable Charles Laymen Terry, Jr., 8 Del. Rptr. 1-19 (West 1973) (publishing supreme court proceedings in memory of Judge Terry). It is a tribute to Terry that the most common salutation remained "Judge Terry," a fond and affectionate remembrance of his close relationship with the trial bar and his dominant presence in the courthouse setting.

23. Glanding, 45 A.2d at 556.

24. Id. at 555 .

25. Id. at 556

26. Id. at 557 (quoting 1 POMEROY, supra note 6, $\$ \$ 295,344$ and citing Fox v. Wharton, Del. Ch., 5 Del. Ch. 200 (1878); Kahn v. Orenstein, Del. Ch., 114 A. 165, 167-68 (1921), rev'd on other grounds, Del. Supr., 119 A. 444 (1922); Walker v. Caldwell, Del. Ch., 67 A. 1085 (1896); Hollis, Adm'r v. Kinney, Del. Ch., 120 A. 356, 358 (1923)). 


\section{the line holding that "[s]ection 25 operated as a direct and positive limitation on} the equity jurisdiction."27

The majority elaborated on its conclusion in the following language:

It is, therefore, quite clear to us that the jurisdiction of the Court of Chancery as written by implication into the constitution of 1776 is as that set forth under Section 21 of the Act of 1726-1736 [the Gordon Statute], and Section 25 thereof represents nothing more than a legislative direction or declaration of what would have existed without it, and did not operate as a restriction or limitation of the exercise of equitable jurisdiction. Therefore, the equitable jurisdiction under the constitution of 1776 embodied that complete system of equity jurisprudence as administered by the High Court of Chancery of Great Britain and as brought to this country by the colonists and later enacted into the statute of 1726-1736, subject only to the proper application of the ancient rule that equity will not assume to exercise jurisdiction where there exists a complete and adequate remedy at law. Although the Legislature under subsequent constitutions has provided for additional equity jurisdiction, yet the underlying principles as established in the constitution of 1776 have not been disturbed. The continuation upon our statute books of the substance of Section 25 of the Act of 17261736, now appearing under Paragraph 4367 of the present Code [REVISED CODE OF DELAWARE 1935], does not alter in any respect our conclusion, as the continuation of a statute containing constitutional provisions is but merely declaratory of the constitutional provision itself and must be construed as such. However, if necessity requires a construction of Paragraph 4367 in the light of equitable jurisdiction aside from the constitution, we say the same in reference thereto that we have heretofore stated regarding Section 25 of the Act of 1726$1736{ }^{28}$

The court chose a general frame of reference in English law over the more narrow frame of reference in the colonial history of Delaware and Pennsylvania. After tracing the statutory history, the majority returned to its original conclusion:

It cannot be said too forcefully that the general powers of the Court of Chancery refers to that complete system of equity as administered by the High Court of Chancery of Great Britain, and a proper interpretation of the constitutions of this State lead to but one conclusion; that is, that the Court of Chancery shall continue to exercise that complete system of equity jurisdiction in all respects until the Legislature of this State shall provide otherwise, as by granting the exercise of a part of that jurisdiction exclusively to some other tribunal. ${ }^{29}$

The majority then recognized the argument that the remedy at law was "adequate and complete," and, therefore, even under the ancient rule equity would not exercise its concurrent jurisdiction. But the majority held that:

Nevertheless, there are well-recognized exceptions to this rule, and a concurrent jurisdiction will be found to exist in many cases where the legal remedy afforded

27. Id. (citing Beeson v. Elliott, Del. Ch., 1 Del. Ch. 368, 386 (1831); Jefferson v. Tunnell, Del. Ch., 2 Del. Ch. 135 (1847); Equitable Guarantee \& Trust Co. v. Donahoe, Del. Ch., 45 A. 583 (1900)).

28. Id.

29. Id. at $558-59$. 
is adequate and complete in all respects. For example, whenever the statutes conferring the new jurisdiction upon the Law Courts are permissive only, or whenever they not only do not contain any expressed prohibitory language, but also do not indicate from all their provisions taken together, any clear intent to restrict the equitable jurisdiction, that jurisdiction remains unaffected, and may still be exercised; even though the rights protected and the remedies conferred have by the statutes been made legal, and even though a relief ordinarily sufficient, even amply sufficient and complete, may be obtained through the actions at law. Of course, the effect of the statute creating the legal remedy depends upon the legislative intent, and unless the statute shows a clear and certain intent that the equitable jurisdiction is no longer to be exercised under the matters within the scope of the statute, then the equitable jurisdiction has not been abrogated. ${ }^{30}$

Primary reliance for the rationale was placed on John Norton Pomeroy's treatise on equity jurisprudence, particularly on its position that equity jurisdiction is not lost by the law courts' acquisition of jurisdiction over matters once exclusively handled by equity courts. ${ }^{31}$ The majority also relied on the specific application of this general principle to probate courts. ${ }^{32}$ With regard to the statute that allegedly abrogated the constitutional equity jurisdiction in the court of chancery, the court ruled, that to abrogate the court of chancery's jurisdiction, exclusive jurisdiction would have had to have been expressly placed in the orphans' court or so placed by necessary implication. Because the court found no such intent in the "permissive or conditional jurisdiction" under the orphans' court statute, it concluded that concurrent equity jurisdiction remained in the court of chancery.

The majority made one interesting comment near the end of its opinion that perhaps helps explain the result and choice of the majority on this relatively open question:

We are not unmindful of the growing tendency on the part of Courts of other
jurisdictions to read into all legislative enactments, conferring new legal remedies
over matters theretofore reposed in equity, a legislative intention to make the
remedy at law, if adequate, exclusive. The source of our equity jurisdiction and
its development by our able Chancellors forbids us from concurring in such a
construction or interpretation of any statute conferring a new legal remedy
unless it be clear from the language employed therein that the Legislature
intended by said enactment to abrogate the pre-existing equitable jurisdiction.

The court may well have been influenced by the fact that the chancellor had been the chief judicial officer in the state for 153 years. Strangely, under the original Constitution of 1897, before 1951, the orphans' court consisted of the chancellor and the resident law judge in each county. One judge was a quorum, although both could sit. The appeal was to the superior court, not the old

30. Id. at 559.

31. POMEROY, supra note $6, \S 182$.

32. 4 id. $\$ 1153$. For some unknown reason, the majority cited an earlier third edition for this point. Glanding, 45 A.2d at 559 .

33. Glanding, 45 A.2d at 560 (emphasis added). 
supreme court. ${ }^{34}$ One cannot help but think that the court pragmatically tried to enhance the chancellor's role, given the possibility of complex questions of law in the estate field.

The dissent, written by no less a scholar than Judge Rodney, ${ }^{35}$ did not take issue with the constitutional grant of equity jurisdiction originating in section twenty-one of the Gordon Statute, nor did it dispute that section twenty-five was declaratory of a preexisting rule of equity. It balked, however, at entirely disregarding the statute. Judge Rodney started with the proposition that the concurrent jurisdiction of equity was based on the use of equitable remedies to enforce legal rights, and that it was not exercised if there was an adequate remedy at law. He then recognized that there were two views on the survival of equity jurisdiction when law is expanded by statute to supply an adequate legal remedy in an area of preexisting equitable jurisdiction. Under one view, the adequate remedy provided in the statute ended the equity jurisdiction. Under the second view, Judge Rodney acknowledged that the statute "must use words negativing or expressly taking away the equitable jurisdiction." 36 But, even under the second view, the minority found that the continuing declaration of the "sufficient remedy" limitation by statute, plus the new statutory grant to the orphans' court expressly indicated a legislative intent to end equity jurisdiction.

Thus, the point of difference was narrow. Both opinions recognized that a general equity jurisdiction of the court of chancery, coextensive with that of the High Court of Chancery of Great Britain, became constitutionally vested in the court of chancery in 1792 . Both recognized that the traditional, adequate remedy at law limitation applied to that constitutional jurisdiction. Both also recognized that the adequate remedy at law restriction did not necessarily apply when legal remedies were being expanded into areas previously occupied by equity, unless the legislature intended to make the legal remedy exclusive. The majority found no such intent, while the minority found a continuing declared intent existed in the successor to section twenty-five of the Gordon Statute. ${ }^{37}$

While Glanding focused on the "sufficient remedy" limitation contained in section twenty-five of the Gordon Statute, it also "finally settled" that the "constitutionally prescribed jurisdiction of the Court of Chancery" was "coextensive with the system of equity jurisdiction administered by the High Court of Chancery of Great Britain ...."38 That is, while the General Assembly can divest the court of chancery of its constitutional jurisdiction by

34. See Del. CONST. of 1897 , art. IV, $\$ \S 13-14$, in ReviSED CODE OF DELAWARE 1935, at xxix.

35. Richard S. Rodney served as Judge of the Superior Court (1922-1946) and United States District Judge (1946-1963). Judge Rodney had a keen interest in history and wrote extensively. See THE COllected EsSAYS OF RichaRd S. RodNEY ON EARLY DELAWARE (George H. Gibson ed., 1975). He died in 1963 at the age of 81. See also Proceedings in Memory of the Late Honorable Richard Seymour Rodney, in 5 Del. Rptr. 1-21 (West 1971) (publishing supreme court proceedings in memory of Judge Rodney).

36. Glanding, 45 A.2d at 566 .

37. See supra note 19 and accompanying text.

38. Delaware Trust Co. v. McCune, Del. Ch., 80 A.2d 507, 509 (1951), an opinion by then Chancellor Daniel F. Wolcott. See infra note 43. 
providing a full, adequate, and complete remedy at law, such divesture does not occur unless the General Assembly expressly states or necessarily implies that the legal remedy is exclusive. Constitutional equity had been established.

\section{B. Glanding's Loose Ends}

Historical glimpses, by their nature, are difficult because history continues. Glanding, in itself a rarity, is an appropriate stopping point, but stopping would leave three important jurisdictional loose ends. Unfortunately, they cannot be disposed of summarily. First, and foremost historically, a second round of the Glanding battle occurred in $d u$ Pont $v . d u$ Pont,$^{39}$ and, because $d u$ Pont is not only commonly cited with, but also is essential to an understanding of Glanding, it cannot be ignored. Second, there is the second limitation in section twentyfive of the Gordon Statute, concerning the reference of factual issues to the law court for a jury trial. While it has received less attention than the "sufficient remedy" limitation, it is important to trace its origins. Third, there is a need to generalize, to place the specific historical sketch into the general equity context.

1. $d u$ Pont v. $d u$ Pont. The $d u$ Pont case is interesting for many reasons. It was decided in the court of chancery by Vice Chancellor Seitz on March 22, $1951 .^{40}$ Less than two months later, effective May 14, 1951, a major judicial reform was effectuated by a constitutional amendment that created an independent, three justice supreme court. ${ }^{41}$ Thus, a new court heard the $d u$ Pont appeal. But one judge, superior court Judge Terry, who sat in the 1945 Glanding appeal to the old supreme court, also sat in the $1951 \mathrm{du}$ Pont appeal because the newly appointed Chief Justice, Clarence A. Southerland, was disqualified. ${ }^{42}$

In the $d u$ Pont case, a wife sued for separate maintenance. The General Assembly had purported to give exclusive jurisdiction to the family court in a quasi-criminal action for the support of a deserted wife in destitute circumstances. The question was whether the court of chancery retained separate maintenance jurisdiction. In a two-to-one decision, the court upheld the jurisdiction of the court of chancery.

The majority decision was written by Justice Wolcott, ${ }^{43}$ with Judge Terry

39. Del. Supr., 85 A.2d 724 (1951).

40. du Pont v. du Pont, Del. Ch., 79 A.2d 680 (1951). Collins J. Seitz, appointed vice-chancellor in 1946, became the state's fourteenth chancellor in June of 1951 and served until his appointment to the Federal Court of Appeals for the Third Circuit in 1966. He served as Chief Judge of the Court of Appeals from 1971 to 1984 . He continues to serve on senior status and recently participated in Planned Parenthood v. Casey, 947 F.2d 682 (3d Cir. 1991), the case involving the Pennsylvania abortion statute which was recently considered by the United States Supreme Court. See Planned Parenthood v. Casey, 112 S. Ct. 2791 (1992).

41. 48 Del. Laws, ch. 109 (1951). The three new justices took office in June 1951.

42. See Del. Const. Of 1897 art. IV, \& 12, in 1 DEL. CODE ANN. 265 (rev. 1974) (provision governing designation of temporary judges to the supreme court).

43. Daniel F. Wolcott had served briefly as a judge on the superior court in 1949-1950 and as the state's thirteenth chancellor in 1950-1951, before being appointed as a justice to the new supreme court. 
joining. Interestingly, the court, on its own motion, considered first a constitutional issue that had been assumed in Glanding: Could the General Assembly "expressly deprive chancery of jurisdiction without at the same time creating a sufficient remedy in some other tribunal"?" This question was not "technically" decided in Glanding, because the remedy afforded by the orphans' court "was admittedly sufficient in that case." 45

The heart of the dispute between the majority and the minority in $d u$ Pont focused on a constitutional provision added by the 1831 Constitution, continued in the 1897 Constitution, granting the General Assembly "power to repeal or alter any Act of the General Assembly giving jurisdiction to ... the Court of Chancery, in any matter, or giving any power to either [sic] of said courts."46

The majority found this constitutional provision, which was rather sweeping in its full language, and which had not in fact been considered in Glanding, conferred no authorization on the General Assembly to "repeal or alter" the portion of equity jurisdiction that had been constitutionally "vested" in the chancellor by the Constitution of 1792 , and continually "vested" in the court of chancery by the Constitutions of 1831 and $1897 .^{47}$ The majority held that the word "giving," in "giving jurisdiction to," referred only to jurisdiction legislatively given since the adoption of the 1792 Constitution and distinguished such given jurisdiction from that which was "vested" in 1792.48

The result, therefore, was the same as Glanding. The "general equity jurisdiction of the Court of Chancery [was] measured in terms of the general equity jurisdiction of the High Court of Chancery of Great Britain and [was] a constitutional grant not subject to legislative curtailment," except as the traditional limitation of equity-an adequate remedy of law-itself restricted in Glanding, curtailed it. ${ }^{49}$

Newly selected Justice Tunnell wrote a blistering dissent to this majority opinion. ${ }^{50}$ The dissent's reasoning was powerful and, if it had a fault, it was in

He was appointed chief justice of the supreme court in 1964 and served until his death in 1973 . It is interesting to note that his father, Josiah 0 . Wolcott, had served as the state's eleventh chancellor from 1921 to 1938, and his grandfather, James L. Wolcott, had served as the state's eighth chancellor from 1892 to 1895. See Proceedings in Memory of the Late Honorable Daniel F. Wolcott, 10 DEL. RPTR. 1-22 (West 1974) (publishing supreme court proceedings in memory of Chief Justice Wolcott).

44. du Pont, 85 A.2d at 727.

45. Id.

46. The language now appears in article IV, $\S 17$ of the amended Delaware Constitution of 1897. The use of the word "either" is questioned because several courts are listed.

47. du Pont, 85 A.2d at 729. See also DEL. CONST. of 1792, art. VI, $\S 14$. DEL. CONST. of 1831, art. VI, $\S 5$; DEL. CONST. of 1897 , art. IV, $\$ 10$.

48. du Pont, 85 A.2d at $728-29$.

49. Id. at 729 .

50. James M. Tunnell, Jr., a Rhodes scholar, served on the supreme court from 1951 to 1954 . He thereafter practiced law in Wilmington as one of Delaware's most prominent lawyers with the firm of Morris, Nichols, Arsht, and Tunnell. He was a distinguished visiting professor to the Widener University School of Law. He ran for the United States Senate twice, losing the Democratic nomination in 1954 and losing in the general election of 1966. When Professor William Cary was noting the political ties of Delaware judges, he listed Tunnell as having no public record. William L. Cary, Federalism and Corporate Law: Reflections Upon Delaware, 83 YALE L.J. 663, 691 (1974). Justice Tunnell, in 
its overstatement. Justice Tunnell denied that the "underlying implications" of Glanding supported the majority position, ${ }^{51}$ when clearly they did. In addition, he spoke personally of the majority, writing "[a]s a coup de grace to this dissent," 52 which was clearly not the majority's intent. But, stripped of its overstatement, Justice Tunnell's dissent gave a powerful challenge to the whole Glanding doctrine, a challenge founded in literal constitutional language and history. The major points given were as follows:

(1) "The 1831 constitutional convention was primarily aimed at reform of the judiciary." There is no reason to limit the "power to repeal or alter" given to the General Assembly. ${ }^{53}$

(2) The 1831 Constitution only guaranteed jurisdiction to the Superior Court, that is, general common law jurisdiction. Every other court and the statutory jurisdiction of the Superior Court was subject to legislative curtailment including the Court of Chancery. The absence of constitutionally guaranteed general jurisdiction in an equity court was not unusual and Pomeroy had "expressly state[d] that Delaware [was] one of that large group of states in which equity jurisdiction may be abridged, restricted, or modified by statute."54

(3) The distinction between "vested" and "given" was tortured, especially given the use of the word "vested" elsewhere in the 1831 Constitution. $^{55}$

(4) There had always been a statute giving the Court of Chancery equity jurisdiction as the successor to the statutory equity jurisdiction given to the colonial Court of Common Pleas. See the current DEL. CODE ANN. tit. 10, $1953 \S 341$. Compare the current DEL. CODE ANN. tit. 10, $\S 541$ (1953), which expressly recognizes the constitutional jurisdiction of the Superior Court. ${ }^{56}$

(5) The statutory "sufficient remedy" limitation was directed to the Court of Chancery's power and not to the power of the General Assembly. There was no basis in the statutory language to require the new statutory remedy to be the equivalent of the Chancery remedy or to require that the ouster be by express language. ${ }^{57}$

characteristic wit, is reputed anecdotally to have responded, "I knew we lost but I didn't think we lost that badly." He died on January 6, 1986, at the age of 75. See Memorial Session in Honor of Justice James M. Tunnell, Jr., 38 DEL. RPTR. xxvi-xl (West 1992) (publishing supreme court proceedings in memory of Justice Tunnell).

51. du Pont, 85 A.2d at 740 .

52. Id.

53. Id. at 735 .

54. Id. at 737 .

55. Id. at 738 .

56. Id. at 739 .

57. Id. at 738 . 
(6) By transferring in 1792 the statutory equity jurisdiction "heretofore exercised" by the Court of Common Pleas, the second Constitution did not change its statutory nature. "By transferring the mutable, it became immutable. Non sequitur." 58

Justice Tunnell concluded, "[W] is entirely for the judgment of the General Assembly, and this court's views as to its adequacy are unimportant., 59

By definition, the majority view prevailed. Constitutional equity survived. For reasons not pertinent to our general jurisdiction inquiry, the majority went on to hold that the particular family court remedy was not the equivalent of a separate maintenance action in the court of chancery. But a necessary step in that process is generally important to our inquiry. The majority directed its attention to whether "actions for separate maintenance were maintainable by the wife in England prior to the separation ...." ${ }^{\prime 60}$ The majority concluded that the Ecclesiastical Courts, in "alimony" cases, were the jurisdictional source of independent separate maintenance actions, that is, actions for separate maintenance not joined with any other equitable claim that would support chancery jurisdiction. But since Delaware had not established Ecclesiastical Courts and "[a]t common law, a wife had an absolute right to be maintained by her husband" but was without adequate means of enforcement, equity would supply a remedy. ${ }^{61}$ The Court noted:

The result of the failure to establish Ecclesiastical Courts in Delaware was to leave a void in the system of jurisprudence which was brought to the colonies along with other English institutions. This being the fact, there can be little doubt but that the ancient maxim that Equity will suffer no right to be without a remedy would have been applied in the Courts of Equity of Delaware to give a deserted wife separate maintenance, which she could have had in England in the Ecclesiastical Court but could have in Delaware only in a Court of Equity. After the passage of the Act of 1726-1736, therefore, the Courts of Equity of Delaware had jurisdiction to award separate maintenance to a deserted wife as a part of their original general jurisdiction growing out of the maxim that Equity will suffer no right to be without a remedy. ${ }^{62}$

The majority added:

This maxim is the fundamental source of all general equity jurisdiction. Whenever there exists a legal, as opposed to a purely moral right, which is either not recognized by the law courts, or for which the remedy administered by the law courts is inadequate, incomplete or uncertain, the maxim will be applied by a Court of Equity in support of its jurisdiction to give relief. ${ }^{63}$

58. Id. at 739 .

59. Id. at 735 .

60. Id. at 730 .

61. Id. at $732-33$

62. Id. at 733 .

63. Id. at 733 n.20 (citing 2 POMEROY, supra note $6, \S 424$. 
Thus, while the court looked for the general equity powers held by the High Court of Chancery of Great Britain "prior to the separation," it took a broad principled view of those powers as opposed to a specific cause of action view. The majority also had treated the case as one of first impression: "As far as can be ascertained, the present case is the only instance of an action for separate maintenance having been filed by a wife in the Delaware Court of Chancery." Thus, in 1951, the court of chancery should have entertained separate maintenance jurisdiction, because "prior to the separation," the High Court of Chancery would not have permitted a legal right to be without a remedy, even though the English court itself did not exercise separate maintenance jurisdiction due to the existence of an adequate remedy in the Ecclesiastical Courts.

Three brief comments about the du Pont case should be made. First, although the supreme court was apparently unaware of the exercise of separate maintenance jurisdiction by courts of equity of both the Lower Three Counties in colonial times prior to 1776 and the state of Delaware prior to 1792, the result is consistent with the eighteenth century history. In particular, Fisher v. Fisher, a 1743 Sussex County action for separate maintenance, Robinson v. Robinson, a 1783 Kent County action for separate maintenance, Smith v. Smith, a 1785 Sussex County action for "alimony," and Dick v. Dick, a 1791-92 New Castle County case for separate maintenance, illustrate, and in fact actually demonstrate, before the 1792 Chancellorship, the exercise of the equitable separate maintenance jurisdiction, a jurisdiction that the supreme court in 1951 found abstractly existed. ${ }^{65}$

Second, the court's reliance in du Pont on a general maxim ("equity will suffer no right to be without a remedy") to establish equity jurisdiction is important, because it tempers the bounds of the historical constitutional approach. The Delaware Court of Chancery's general equity jurisdiction is not frozen by what the High Court of Chancery of Great Britain did; it can look at what that court would have done if it had been faced with these circumstances. In short, the creative and innovative function of equity can operate through historically recognized general equitable maxims.

Third, the post-du Pont result regarding the curtailment of constitutional general equity jurisdiction by statute should be highlighted in capsule form. The substituted statutory remedy must be adequate and exclusive. In Glanding, it was conceded to be adequate but found not to be exclusive. In $d u$ Pont, it was conceded to be exclusive but found not to be adequate. The two cases combine to restrict the "sufficient remedy" limitation of the first clause of section twentyfive of the Gordon Statute. To state it positively, the two cases support the retention of jurisdiction in the court of chancery. This is especially true since the

64. Id. at 730 .

65. See Quillen, Equity Jurisdiction, supra note *, at 25-30. For more detail, see Quillen, Historical Sketch, supra note *, at 9,107-10. The original case records are in the Hall of Records, Division of Historical and Cultural Affairs, Department of State, Dover, Delaware. 
court of chancery and the supreme court (on appeal) are the constitutional decisionmakers.

2. Section Twenty-five of the Gordon Statute. The second post-Glanding loose end is the second limitation found in section twenty-five of the Gordon Statute:

[A]nd when matters of fact shall happen to arise upon their examination or
hearing of the matters and causes to be heard and determined in the said Court,
then and in every such case, they shall order the matter of fact to issue and trial
at the Court of Common Pleas for the proper county where the fact ariseth,
before they proceed to sentence or decree in the said Court of Equity.

Ironically, a 1710 Pennsylvania statute originally containing this clause was repealed in England in 1713. ${ }^{67}$ This second clause was the reason. To quote Lord Raymond, the solicitor general:

\begin{abstract}
In relation to the proceedings in equity there is a clause that they shall determine nothing determinable at common law nor try any fact arising on hearing the cause, but send it to an issue at law, which I apprehend must make proceedings in equity insufferably dilatory and multiply trials at law in the plain cases to no manner of purpose, for which reason I am humbly of opinion that this act ought to be repealed. ${ }^{68}$
\end{abstract}

Thus, this provision was certainly not viewed in England as being declaratory of any ancient equitable principle. Nor, due to its less noble origin and the practical problems cited by the solicitor general, was it ever elevated in Delaware to constitutional status, as was the "sufficient remedy" limitation. It apparently lay quite dormant as a mere statute. ${ }^{69}$ Then it received gradually diminishing recognition by both the General Assembly and the courts.

The Court of Errors and Appeals, then the state court of last resort, had occasion to comment on the second clause in Waters v. Comly. ${ }^{70}$ The chancellor

66. 1 DEL. LAwS ch. LIV, 132.

67. The original 1681 grant of Charles II to William Penn reserved a royal power to nullify Pennsylvania statutes. 2 BenJamin P. PoORE, The Federal and State Constitutions, Colonial

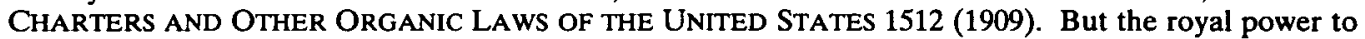
nullify Pennsylvania statutes contained in the 1681 royal grant of the Province (later Pennsylvania) did not include the Territories (later Delaware). Penn himself brought the Territories within the Province's statutes by the 1682 Act of Union, and later placed the Territories beyond them by the permissive terms of his 1701 Codicil, which permitted an independent Assembly in the Territories. The irony was that Penn's Governors, whose appointment the Crown had been careful to reserve as its own, independent of Penn, had no precise direction to forward to England for review the statutes enacted by the independent Assembly of the Lower Three Counties (as the Territories became known). More importantly, the Governors did not forward the colonial statutes of the Lower Three Counties, and nullification was never exercised. Starting slowly with just two laws in 1704, which reaffirmed all previous laws and established the representation and size of the Assembly, the new separate Assembly quickly became an active, independent legislative body. JOHN MUNROE, COLONIAL DELAWARE 120-24 (1978).

68. 2 STATUTES AT LARGE OF PENNSYLVANIA 548-49 (1896), noted in LoYD, supra note 16, at 175.

69. The word "apparently" is used because it is impossible to say with any assurance, if, prior to published cases, the clause played any role in equity practice.

70. Del. Ct. of Err. \& App., 3 Del. (3 Harr.) 117 (1840). 
had refused to refer certain factual issues to the superior court. Counsel supporting that decision argued that the chancery, as a constitutional court after 1792 and 1831, had "the common law power of English courts of equity in sending issues, and no other," and that the decision was purely discretionary and not subject to appeal. ${ }^{71}$ The provision of the Gordon Statute was seemingly not applicable under this view. The other side found the right of reference "too plain for argument" since "[t]he act of assembly [gave] a right to the issue if asked for in proper time." ${ }^{\prime 2}$ The Court seemed to recognize the right but limited it:

\begin{abstract}
As to the refusal of the chancellor to order certain proposed issues of fact to be tried at the bar of the Superior Court, we are clearly of opinion, that the provision of the act of assembly which directs it to be done, must be understood as referring only to issues of fact which involve the merits of the case, and are material to the decision of the cause, which we do not conceive to have been the character of those proposed in the present instance. ${ }^{73}$
\end{abstract}

In the Revised Code of 1852, the language of the clause was altered to read as follows: "[A]nd when matters of fact, proper to be tried by a jury, shall arise in any cause depending in chancery, the chancellor shall order such facts to trial by issues at the bar of the Superior Court." 74 This language was continued in the Codes of 1915 and $1935 .^{75}$

The first interpretation of the amended statutory language was made by Chancellor Bates in Sparks v. Farmers' Bank. ${ }^{76}$ Although the statute used the word "shall," which indicated a mandatory legislative directive to the chancellor to submit "matters of fact proper to be tried by a jury" to trial in the superior court, the chancellor simply said: "The application is one made to the sound discretion of the Court." 77

If any question remained concerning the correctness of Chancellor Bates' statutory interpretation, the matter was put to rest, prior to the 1951 court reform constitutional amendment, by the law judges sitting as the supreme court in Saunders $v$. Saunders. ${ }^{78}$ Judge Terry wrote:

Whatever import may be given to the Court's language in the Waters case, ... decided under the statute of 1792 , it must be said that our Chancellors, since the Bates decision in the Sparks case, ... , under the statute of 1852, Section 4367, Code of 1935 , have consistently indicated in the very few cases presented that

71. Id. at 119 .

72. Id. at 120 (emphasis in original).

73. Id. at 130. See also McDowell v. Bank of Wilmington \& Brandywine, Del. Ct. of Err. \& App., 1 Del. (1 Harr.) 369, 384 (1834).

74. REv. STATUTES OF 1852, ch. 95, § 1, II 1933 (Dover, Del., Samuel Kimmey 1852) (emphasis added).

75. Revised Code of Delaware 1915, ch. 117, $\mathbb{1}$ 3844; ReVised Code of Delaware 1935, ch. 117, II 4367.

76. Del. Ch., 3 Del. Ch. 225, 230 (1868).

77. Id.

78. Del. Supr., 71 A.2d 258, 261-62 (1950). 
the granting of an application to direct an issue to be tried by a jury at law is not a matter of right, but falls completely within the sound discretion of the Court. $* * *$

If a cause is properly in the Court of Chancery, we find no right to exist in either party to the litigation to say that a fact necessary to be determined in the course of the proceeding, although it may be said to be a subject for cognizance in a Court of Law before a jury, cannot also be determined in equity without the intervention of a jury.

To construe the second clause of Paragraph 2 of Section 4367 otherwise would be to render it an infringement upon the inherent jurisdiction of the Court of Equity. ${ }^{79}$

Thus, notwithstanding their common origin in the Gordon Statute, Judge Terry suggested that the second clause could not constitutionally infringe on the general equity jurisdiction. The deference implicit in the reference to "our Chancellors" is also worthy of passing note.

With the 1953 Code revision, the codifiers expressly confirmed what the Court had done. The new provision still reads as follows:

When matters of fact, proper to be tried by a jury, arise in any cause depending in Chancery, the Court of Chancery may order such facts to trial by issues at the Bar of the Superior Court. ${ }^{80}$

The revision note said simply: "[The w]ord 'may' was substituted for 'shall' in order to make the ordering of facts to trial permissive rather than mandatory, and so to conform these provisions to present practice." 81

But even that does not end the matter. Long before Saunders, the court of chancery, in Scotton $v$. Wright, noted that the verdict obtained when issues were sent by it to the superior court for trial by jury was advisory only, and was not binding on the chancellor. ${ }^{82}$ While the point has not arisen directly, the Scotton comment was accepted as law in Getty Refining \& Marketing Co. v. Park Oil, Inc. ${ }^{83}$ and tied into the present statute. ${ }^{84}$ Thus, now not only is the jury trial reference discretionary, but the jury's verdict is only advisory. Lest anyone question this change, Vice Chancellor Hartnett said in Getty: "The old procedure of framing of issues by the Court of Chancery for jury trial is now probably outmoded ....".85

79. Id. The reference to the "statute of 1792" is a mistake, since the statute in question is the Gordon Statute, 1 Del. Laws, ch. LIV, and this makes some of the opinion's chronology in error. The court's opinion also excepts the issue of land title from its general permission to try factual issues in chancery. Dill v. Dill, Del. Ch., 91 A. 450, 452 (1914).

80. DEL. CODE ANN. tit. 10, § 369 (1953).

81. Id.

82. Del. Ch., 122 A. 541,542 (1923).

83. DEL. CODE ANN. tit. 10, \$369 (1953).

84. Del. Ch., 385 A.2d 147, 151 (1978).

85. Getty Refining \& Marketing Co., 385 A.2d at 151. 
Thus, over 200 years after the enactment of the Gordon Statute, the second clause of section twenty-five became surplusage. It is no more than the traditional discretion of an English chancellor to have an advisory jury. It has no force as a statutory limitation. To that extent, it is similar to the "sufficient remedy" clause; both clauses invoke the inherent and traditional aspects of general equity jurisdiction, but neither has a mandatory effect as a statute.

While the crucial litigation has related to section twenty-five of the Gordon Statute, the most important consequence stems from section twenty-one and the preliminary focus of Glanding. The Delaware Court of Chancery is constitutionally established as an independent court of general equity jurisdiction, with that jurisdiction being measured by that of the High Court of Chancery of Great Britain at the time of the separation. ${ }^{86}$ This statement is not incontrovertible. It is possible to suggest, as Justice Tunnell does effectively in his du Pont dissent, that this constitutional jurisdiction has been made out of whole cloth. Indeed, when one recognizes that the language of section twenty-five of the Gordon Statute came from the 1710 Pennsylvania statute and was part of the battle between the Governor and the Assembly in the Province over chancery jurisdiction, it is difficult to justify the interpretations eliminating any statutory role for the two clauses. In short, the historical context giving rise to the limiting clauses was specific, not general, was Pennsylvania, not England, and was one of reform, not preservation. Nor does the first state constitution lend any support for the broad nonstatutory Glanding view. ${ }^{87}$ Nonetheless, constitutional equity is a done deal. There remains only to put a specific historical concept into a general equity context.

3. General Equity. History has been kind to equity in Delaware. The preEnglish legal structure under the Swedes and Dutch (1636-1664) resembled equity more than common law procedure. The early (late 1600s) and loosely defined concept of "equity" under the English was exercised relatively infrequently, as a post-trial or appellate corrective device. The development of original bill in equity in the early 1700s was in the regular law courts, and was not jurisdictionally competitive. The courts of equity, pursuant to a colonial statute, played a particularly useful eighteenth century role in perpetuating testimony in the very important matter of land titles. Equity was not viewed with disfavor. Thereafter, probably for reasons unrelated to any jurisdictional

86. The separation, of course, was in 1776. From 1776 to 1792 , under the Constitution of 1776, the court of common pleas exercised equity jurisdiction expressly subject to statutory curtailment. From 1792 forward, general equity jurisdiction previously exercised by the Court of Common Pleas was constitutionally vested in the court of chancery under article VI, $\S 14$ of Delaware's Constitution of 1792 . It is not always clear in the cases whether the crucial date to measure the jurisdiction of the High Court of Chancery of Great Britain is 1776 or 1792 . See, e.g., Beals v. Washington Int'l, Inc., Del. Ch., 386 A.2d 1156, 1158 (1978); M.F. v. F., Del. Ch., 172 A.2d 274, 277 (1961). The date set forth in Glanding, 45 A.2d at 557, and confirmed in $d u$ Pont, 85 A.2d at 727, is 1776.

87. "The Justices of the Courts of Common Pleas and Orphans Courts shall have the power of holding Inferior Courts of Chancery as heretofore unless the Legislature shall otherwise direct." DEL. CONST. of 1776 art. XIII. 
need, an independent position of chancellor was created, and, at the time of Glanding, for over 150 years, the chancellor had been the state's chief judicial officer. ${ }^{88}$

It is worth re-emphasizing that, up until the creation of the independent supreme court in 1951, only thirteen men had served as chancellor. In a real sense, the chancellor was the human embodiment of the whole judicial system. The chancellor administered general equity jurisdiction, and presided over the court of last resort when it finally determined appeals at law. There was a very personal presence. The office of Chancellor was the man.

Thus, the retrospective context in 1945 (at the time of Glanding) was different from the proprietorship context in 1727 under Governor Gordon. And the tough constitutional question was not expressly raised in Glanding. It was not raised until the $d u$ Pont case. By that time, the die had been cast. Judge Terry had voted, and written the majority opinion in Glanding. Justice Wolcott, writing as chancellor in 1951, the same year $d u$ Pont was decided, had cast a vote of his own in Delaware Trust v. McCune. ${ }^{89}$

The equity jurisdiction, so limited in its origin, but embodied in the chancellor in 1792, had become a symbol of permanence by 1951 . Justice Wolcott absolutely clarified this point in $d u$ Pont. Constitutions were to secure "unchangeable rights and remedies," three successive Constitutions intended "to establish for the benefit of the people of the state a tribunal to administer the remedies and principles of equity,"91 and equity jurisdiction was "remove[d] from the vagaries of legislative whim." 92 It was indeed-by a three-to-two vote in $1945,{ }^{93}$ and by a two-to-one vote in $1951 . .^{94}$

\section{III}

\section{MANIFESTATIONS OF DELAWARE'S EQUITY TRADITION}

The Glanding doctrine is approaching its fiftieth birthday. There is, perhaps, no particular reason to suppose that equity jurisdiction in the Delaware Court of Chancery would have been altered had it rested solely on a statutory reed. But, if we examine what has transpired in the last half-century, we cannot help but be impressed by the unusually strong presence of a single state trial court. If nothing can supply absolute linkage, certain manifestations, plus a dash of

88. All of these matters are discussed at some length in Quillen, Historical Sketch, supra note *, at 1-126, and in Quillen, Equity Jurisdiction, supra note *. Particular note should be made of two unpublished works of Michael Hanrahan, Esquire, on which the author relied heavily. See Michael Hanrahan, Colonial Opposition to Chancery Courts (1973) and Delaware Court of Chancery: Delaware's Peculiar Institution (1974). See, in particular, Quillen, Historical Sketch, supra note *, at 114-17.

89. Del. Ch., 80 A.2d 507 (1951).

90. 85 A.2d at 728 .

91. Id. at 729 .

92. Id.

93. Glanding, 45 A.2d 553.

94. du Pont, 85 A.2d 724. 
instinct, tell us that Glanding made a difference. Three manifestations of the presence of the court of chancery stand out.

\section{A. A National Influence}

First, there is the exercise of judicial power on a national level by a state court. This power obviously has a firm base in Delaware's continued status as the home of corporations (over half the nation's 500 largest companies) and the continued favor of the "internal affairs doctrine." W5 While this state of corporate litigation has been subjected to academic criticism over the years, ${ }^{96}$ the internal affairs doctrine continues to flourish. ${ }^{97}$ Thus, the focus on the court of chancery as a forum of first instance in national corporate battles is likely to continue, and cases like Paramount Communications, Inc. v. Time, Inc. ${ }^{98}$ will continue to be litigated "home" in Delaware. This manifestation of power may seem to some oddly provincial in a shrinking world that is becoming economically global. But, while the Delaware Court of Chancery and, on appeal, the Supreme Court of Delaware, may be criticized as pro-management in cases such as Paramount, ${ }^{99}$ and as anti-management for disregarding corporate norms in other cases such as Smith v. Van Gorkom, ${ }^{100}$ the fact is that the Delaware courts decide such cases expeditiously within the framework of the law and let the corporate litigants move on. Unlike so much of government, this system works. Moreover, these decisions are genuinely controversial; good lawyers advocate both for and against the results. One cannot imagine such an academic debate if the forum had not aired the issues in a professional and forthright manner.

If one seeks to evaluate judicial excellence and courage in other subject areas, one has only to remember that one of the four cases included under Brown v. Board of Education ${ }^{101}$ was Gebhart v. Belton, ${ }^{102}$ a Delaware case. In referring to the governing law in Gebhart, Chancellor Seitz stated:

95. The "internal affairs doctrine" is the choice of law rule that applies the law of the state of incorporation to internal affairs lawsuits.

96. See, in particular, Cary, supra note 50, at 663; Comment, Law for Sale: A Study of the Delaware Corporation Law of 1967, 117 U. PA. L. REV. 861 (1969); Note, Little Delaware Makes a Bid for the Organization of Trusts, 33 AM. L. REV. 418 (1899). See also William S. Lerach, The Incorporation Trap: How Delaware Has Destroyed Corporate Governance (1991) (remarks at the National Conference of State Legislatures Annual Meeting, Orlando, Florida, Aug. 11-15, 1991).

97. Kamen v. Kemper Financial Services, Inc., 111 S. Ct., 1711 (1991); CTS Corp. v. Dynamics Corp. of America, 481 U.S. 69 (1987); Edgar v. MITE Corp., 457 U.S. 624 (1982).

98. Del. Supr., 571 A.2d 1140 (1989).

99. See, e.g., Lerach, supra note 96, at 11-15 ("Delaware courts blessed this outrageous insult to the owners of Time as a supposed exercise of business judgment . . . ."). See also Leo Herzel \& Leo Katz, Smith v. Van Gorkom: The Business of Judging Business Judgment, 41 BuS. LAW. 1187 (1986).

100. Del. Supr., 488 A.2d 858 (1985). See, e.g., Leo Herzel, Scott J. Davis \& Dale Colling, Smith Brings Whip Down on Directors' Backs, LEGAL TIMES 14 (May 13, 1985) ("[T]he decision seems to reflect nothing more but the court's need to force haphazardly chosen defendants to repent for the state of Delaware's pro-business ways.").

101. 347 U.S. 483 (1954).

102. Del. Ch., 87 A.2d 862 (1952). 


\begin{abstract}
I, therefore, conclude that while State-imposed segregation in lower education provides Negroes with inferior educational opportunities, such inferiority has not yet been recognized by the United States Supreme Court as violating the Fourteenth Amendment. On the contrary, it has been by implication excluded as a Constitutional factor. It is for that Court to re-examine its doctrine in the light of my finding of fact. ${ }^{103}$
\end{abstract}

It is interesting to note that Collins J. Seitz was thirty-seven years old on the date of the chancery decision in Gebhart, and that a year before, as vice chancellor, he had sat at the trial level in the $d u$ Pont case. While he was the first chancellor not to be the state's highest judicial officer, he obviously knew that he was not a judge of an inferior court.

\title{
B. Jurisdictional Growth
}

Second, the Delaware Court of Chancery presents the phenomenon of a particular species of court, which species is commonly subsumed, and yet, in this state, not only survives, but experiences new and expansive constitutional and legislative recognition. This manifestation seems odd in light of the unification movement that has had widespread support among judicial reformers, both nationally and in Delaware. But any fair review of the last half-century demonstrates extremely significant jurisdictional growth. Some of the growth was particular, such as the movement of inspection of corporate stock lists, and corporate books and records from a legal mandamus action to statutory equitable action. ${ }^{104}$ Some of the growth was judicial reform, such as the constitutional abolition of the orphans' court and the transfer of the bulk of its former jurisdiction to chancery, including appointments of guardians for minors and partitions of real estate. ${ }^{105}$ Part of the expansion is simply using the court of chancery as an instrument to update and professionalize both substantive and procedural law, such as the enactment of an entirely revised probate code. ${ }^{106}$

At a 1985 seminar on Chancery Practice and Procedure, well over 100 statutory references were collected to demonstrate the statutory jurisdiction of the court of chancery. While some of these references were traditional, ${ }^{107}$ many simply reflect the full spectrum of the growth of law, from equal accommodation $^{108}$ to hazardous waste management ${ }^{109}$ to coastal zone protec-

103. Id. at 866. The chancellor went on to hold that the facilities were not equal and ordered integration. The decision was affirmed on this ground. Gebhart v. Belton, Del. Supr., 91 A.2d 137 (1952). It was the defendants who took the case to the United States Supreme Court. The Delaware case was the only one to be affirmed in Brown.

104. 56 Del. Laws ch. 50 (1967); DEL. CODE ANN. tit. 8, § 220 (1953).

105. 57 Del. Laws ch. 402 (1970).

106. 59 Del. Laws ch. 384 (1974). DEL. Code ANN. tit. 12, chs. 1, 5, 9, 13, 15, 17, 19, 21, 23, 25 \& 27.

107. For example, certain provisions of partnership law. DEL. CoDE ANN. tit. 6, $\$ \S 17-802,803$ (1986, 1990).

108. Id. ch. 45 (1953).

109. Id. tit. 7, § 6309 (1984). 
tion $^{110}$ to cable television franchises. ${ }^{111}$ In the strange world of judicial process, courts must grow to protect their institutional independence. Bureaucracy itself is necessary, both to reflect the complexities of modern life, and to provide the resources to compete in relation to the other branches of government. So accepted is chancery's permanence in Delaware that these influxes of life's necessities have gravitated to the court without any need of judicial advocacy. The challenge to the court, now expanded to five judges, all of whom currently are outstanding jurists, is to handle its success and to preserve the strong singularity of its traditional identity. In the words of one commentator, it is "the obligation of a judge to engage in a special dialogue-to listen to all grievances, hear from all the interests affected, and give reasons for his decisions," thus assuring "the parties that he has thoroughly participated in that process and assumes individual responsibility for the decision." 112 In short, the court, so permanently established in the body politic, has met, through growth, the challenge of institutional survival, but now faces the challenge of maintaining a personal judicial presence.

\section{The Cultural Legacy}

Third, a cuitural manifestation exists concerning the court of chancery. The judges often write with a devotional attachment to the court's history, and with a respectful, yet zestful, reliance on equitable concepts and maxims that predate the nation. This manifestation seems odd in a world where law is changing at a rate that few lawyers can fathom, in a modern mode that is legislatively driven, as distinct from common law increments, and involves substantive areas and peculiar expertise that were nonexistent only a generation ago. In this mix, at the least, the Glanding doctrine reinforces a heritage that carries an obligation to history. The doctrine expressly takes us back to the core concept. The heritage of equity is the ethical tradition of the ecclesiastical chancellors, the tradition of equity and good conscience, complemented by the early heritage of royal dispensation "for God and in way of charity" on the behalf of the disadvantaged and, from the $1400 \mathrm{~s}$, by the particular moral persuasion involved in the enforcement of uses. ${ }^{113}$ Equity is simply a moral sense of fairness in a legal context. Chancellor Ellesmere, in The Earl of Oxford's Case, ${ }^{114}$ put the reason as being simply: "The Cause why there is a Chancery is, for that Mens Actions are so divers and infinite, That it is impossible to make any general Law

110. Id. § 7012 (1953).

111. Id. tit. 6, \& 606 (1974).

112. Owen M. Fiss, The Bureaucratization of the Judiciary, 92 YALE L.J. 1442, 1443 (1983).

113. St. Thomas More was the first lawyer chancellor (1529-1532). He succeeded Cardinal Wolsey (1515-1529) and was described by Maitland as "the last of the great ecclesiastical Chancellors." The last ecclesiastic was Dr. Williams, Bishop of London (1621-1625), and the last non-lawyer was Anthony Ashley Cooper, Earl of Shaftesbury (1672-1673). See FREDERIC MAITLAND, EQUITY 1-11 (1920).

114. 21 Eng. Rep. 485 (Ch. 1615). 
which may aptly meet with every particular Act, and not fail in some Circumstances."115

Ancient principles have modern echoes. Strict legal compliance with the Delaware corporation statute, in changing the bylaw date of the annual meeting, did not suffice, when the court found an inequitable manipulative purpose designed to obstruct a dissident proxy effort. Justice (later Chief Justice) Herrmann hit the core concept well: "[I]nequitable action does not become permissible simply because it is legally possible." 116

Delaware judges, sitting in chancery and in equitable appeals, frequently place heavy reliance on traditional equitable maxims and jurisdictional concepts. In Beals v. Washington International, Inc. ${ }^{117}$ Vice Chancellor Hartnett, finding no Delaware statute granting the court of chancery jurisdiction to impose punitive damages, said it was first "necessary to ascertain whether the high court of chancery in England had such jurisdiction in 1776."118 After lengthy consideration of both English and U.S. precedent, he held "that Chancery historically and traditionally did not enforce forfeitures or penalties and that was the rule in the high court of chancery in England in 1776 and is therefore the rule in this Court today."119 It is interesting to speculate on whether the traditional maxim-"equity abhors a forfeiture"-could play any useful role in today's national debate over tort reform.

In Ryan v. Weiner, ${ }^{120}$ Chancellor Allen cited Justice Story's 1835 treatise, Commentaries on Equity Jurisdiction, a 1750 case of Lord Hardwicke, and innumerable U.S. and English case authorities in three centuries on the subject of unconscionable contracts. Such opinions do more than decide cases; they remind us of who we are and, in the sense of law and constitutions, from where we came.

As RJR Nabisco suggests, perhaps the most troublesome doctrine in Delaware's bifurcated system comes from equity's delight "to do justice and not by halves." 121 In Getty Refining \& Marketing Co. v. Park Oil Inc., ${ }^{122}$ the trial court wrestled with the jury trial considerations presented by the permissive "equity clean-up" doctrine, and the supreme court had no difficulty confirming the jurisdiction assumed on appeal. Indeed, Delaware law seems clear that, once equity jurisdiction has attached, the court of chancery has jurisdiction to enter a purely legal remedy and to enter judgment on a sole surviving purely legal claim. ${ }^{123}$

115. Id. at 486 .

116. Schnell v. Chris-Craft Industries, Inc., Del. Supr., 285 A.2d 437, 439 (1971).

117. Del. Ch., 386 A.2d 1156 (1978).

118. Id. at 1158 .

119. Id. at 1159 .

120. Del. Ch., 610 A.2d 1377 (1992).

121. Del. ch., 576 A.2d 654 (1990).

122. Del. Ch., 385 A.2d 147, 149-52 (1978), aff d, Park Oil, Inc. v. Getty Refining \& Marketing Co., Del. Supr., 407 A.2d 533 (1979).

123. Wilmont Homes v. Weiler, Del. Supr., 202 A.2d 576 (1964); New Castle County Volunteer Firemen's Ass'n v. Belvedere Volunteer Fire Co., Del. Supr., 202 A.2d 800 (1964). 


\section{IV}

\section{CONCLUSION}

It could well be argued of the bifurcated system that the game is not worth the candle. But it is reassuring to have a court dedicated to doing equity, requiring clean hands, aiding the vigilant, doing complete justice, not suffering a wrong to be without a remedy, giving regard to what ought to be done, favoring substance over form, and imputing an intent to fulfill an obligation. In an intricate world, the strength of basic morality can still be fostered well as a separate discipline in a distinct institution.

While each separate block in these manifestations of the court can be discussed without reference to the Glanding and $d u$ Pont cases, it is certainly easier to take the opposite course. The case is simple. The judicially proclaimed status of the court as a constitutionally vested, general equity court has emboldened its judges in the exercise of power, supplied a permanence which has enabled its structure to grow, and given a heightened cultural emphasis to equitable maxims and principles. When one views the modern Delaware Court of Chancery in its complete expanse, with national corporate litigation, probate jurisdiction, supervision of trusts, guardianships for children, the infirm, and the aged, trustees for the mentally ill, real estate partitions, innumerable special statutory remedies, and general equity jurisdiction measured by that of the High Court of Chancery of Great Britain at the time of separation, it is amazing how true the current court is to the tradition of English Chancery.

Even the date 1776 may be lucky. The last century of the High Court of Chancery in England was not its strongest. Delaware's vision of chancery is spared the strangulation of form that became more oppressive in the 1800 s, including the English Chancellor's nineteenth century anti-egalitarian role. ${ }^{124}$

124. In the early nineteenth century, the English Court of Chancery was so burdened by the "arrears of business" that "the time consumed in merely waiting to be heard amounted to a denial of justice." 1 William S. Holdsworth, A History OF ENGLISH LAW 438-39 (7th ed. 1956). Pleadings in equity had become

so long and technically framed, with so many references and qualifications as to be scarcely intelligible to the defendant, who [was] obliged to trust that his solicitor and counsel have, in the voluminous document to which he deposes, accurately translated the brief and somewhat bald notes which the solicitor took down from his mouth.

9 id. at 404 (Little, Brown 1926). Equity, and the common law as well, had become "needlessly expensive ...." Id. at 372 . The two leading chancellors at the turn of the century, Lord Edward Thurlow (1778-1793) and Lord Eldon (John Scott) (1801-1806, 1807-1827), had manners and views that reflected on the institution. Thurlow suffered from a "want of steady industry," "opposed a measure of Pitt's for mitigating the horrors of the slave trade," and "lived openly with a mistress . . ." 12 HOLDSWORTH, supra at 314-27 (Methuen ed., 1938). Eldon "as Chancellor approved legislation, like the Six Acts [a repressive code passed in 1819, see AN ENCYCLOPEDIA OF WORLD HISTORY, ANCIENT, MEDIEVAL AND MODERN, CHRONOLOGICALly ARRANGEd 605 (William L. Langer ed., 1948) for chronology], which was designed to suppress industrial unrest and agitation for reforms." Eldon "opposed the Act which abolished the slave trade, and he was convinced that the smallest reform in the representative system, and the smallest concession to religious non-conformity would shake the foundations of the constitution." 13 HOLDSWORTH, supra at 595-638, particularly 604-06 (Methuen \& Hanbury eds., 1952). Thus, while substantive equitable doctrines were systematized and even new substantive doctrines arose, see, e.g., Tulk v. Moxhay, 2 Phillips 774 (Ch. 1848) (doctrine of equitable 
In 1980, the court of chancery and, on appeal, the supreme court confronted the ultimate life-or-death issue concerning the removal of life-support systems. The language of the supreme court, in an opinion written by Justice Duffy, ${ }^{125}$ a former chancellor, relates the case with grace:

Parenthetically, it is beyond dispute that, in the Delaware judicial system, no other Court has the power, under the common law or by Statute, to grant a "sufficient remedy" to the guardian concerning the withdrawal of life-support systems which now sustain Mrs. Severns. The situation in which Mr. Severns finds himself, then, is this: his wife has a constitutional right to accept or reject medical assistance; she is unconscious and, for that reason, she cannot assert that right; under the ruling made herein, he is the guardian of his wife's person, with standing to assert the right which she cannot voice; there is not a Delaware statute providing for the kind of relief he seeks; he cannot assert his wife's constitutional right in any law Court of this State. Of course the Court of Chancery will grant him relief under those circumstances, if he proves his right to it. That is what equity jurisprudence has been all about since its beginnings. The historic jurisdiction of the Court of Chancery is described in Glanding and more recently, in Du Pont v. Du Pont, .. . but nothing in either of those cases indicates that the fashioning of relief is limited to that which was available in 1776. On the contrary, the very essence of our system of equity, as Pomeroy states in discussing its inherent power to meet social needs, is to render the "jurisprudence as a whole adequate to the social needs .... [I]t possesses an inherent capacity of expansion, so as to keep abreast of each succeeding generation and age." 126

It is nice to have a court with that mission.

servitudes), there was attached to English Chancery a somewhat repressive image.

125. William Duffy has served as a judge of the superior court (1961-1962), as President Judge of the Superior Court (1962-1966), as the state's fifteenth chancellor (1966-1973), and a justice of the supreme court (1973-1982). He retired effective March 31, 1982. He currently serves as a Distinguished Visiting Professor of Law at the Widener University School of Law.

126. Severns v. Wilmington Medical Ctr., Inc., Del. Supr., 421 A.2d 1334, 1347-48 (1980) (footnote omitted) (quoting 1 POMEROY, supra note 6, $\$ 67$ ). 